\title{
PEMANFAATAN EKSTRAK DAUN KELOR (Moringa Oleifera, Lam) SEBAGAI ANTIOKSIDAN PADA MINYAK KELAPA
}

\author{
Livia Fransisca Tulus ${ }^{1}$, Sunarty ${ }^{1}$, F. A. Souhoka² \\ ${ }^{1}$ Departement of Chemistry-FKIP, Pattimura University Ambon \\ ${ }^{2}$ Departement of Chemistry-MIPA, Pattimura University Ambon
}

Diterima 20 Agustus 2018/Disetujui 26 September 2018

\begin{abstract}
This research aims to determine the compounds contained in moringa leaf methanol extract by phytochemical test, values of antioxidant activity and application for coconut oil to determine peroxide value, acid value and moisture content based on oil quality according to SNI 01-374-2013. Result of phytochemical test show that Moringa leaf methanol extract contains of alkaloid, flavonoid, saponin, tannin, terpenoid and fenolik compoundsnm. Test of antioxidant activity with DPPH and measured with a UV-Vis spectrophotometer at wavelength $517 \mathrm{~nm}$. Moringa leaf methanol extract has an IC50 value of $61,625 \%$ so that it is classified as strong antioxidant. The addition of moringa leaf methanol extract $5 \%$ on coconut oil after heating at time variation 15 , 30 , and 40 minutes showed oil quality is better than without addition of extract with peroxide value $((1,1716$, $3,8378$ and $6,6043 \mathrm{Meq} / \mathrm{kg})$, acid value $(0,4700,0,5869$ and $0,7024 \mathrm{KOH} / \mathrm{g})$, and moisture content at $1 \%$ extract concentration $(0,1978,0,1290$ and 0,0896 \%).
\end{abstract}

Keywords: Antioxidant, Moringa Leaf, DPPH, Phytochemical, coconat il, and UV-Vis.

\section{ABSTRAK}

Penelitian ini bertujuan untuk menentukan senyawa yang terkandung dalam ekstrak metanol daun kelor dengan cara uji fitokimia, nilai aktivitas antioksidan, dan aplikasinya pada minyak kelapa untuk menentukan bilangan peroksida, bilangan asam dan kadar air dengan berdasarkan syarat mutu kualitas minyak menurut SNI 01-37412013. Hasil uji fitokimia menunjukkan bahwa ekstrak metanol daun kelor mengandung senyawa alkaloid, flavanoid, saponin, tanin, terpenoid, dan fenolik. Uji aktivitas antioksidan dilakukan dengan menggunakan metode DPPH dan diukur dengan Spektofotometer UV-Vis pada panjang gelombang $517 \mathrm{~nm}$. Ekstrak metanol daun kelor memiliki nilai IC50 61,625\% sehingga tergolong antioksidan kuat. Penambahan ekstrak metanol daun kelor 5\% pada minyak kelapa setelah pemanasan pada variasi waktu 15, 30, dan 45 menit menunjukkan kualitas minyak lebih baik daripada tanpa penambahan ekstrak dengan nilai bilangan peroksida $(1,1716,3,8378$ dan $6,6043 \mathrm{Mek} / \mathrm{kg}$ ), bilangan asam $(0,4700,0,5869$ dan 0,7024 $\mathrm{KOH} / \mathrm{g})$, dan kadar air pada konsentrasi ektstrak $1 \%(0,1978,0,1290$ dan $0,0896 \%)$.

Kata Kunci: antioksidan, daun kelor, DPPH, fitokimia, minyak kelapa dan UV-Vis

\section{PENDAHULUAN}

Kelapa (Cocos nucifera L.) merupakan salah satu tanaman dalam famili Palmae yang sangat lazim ditemukan di daerah tropis. Kelapa sangat popular di masyarakat karena memiliki banyak manfaat bagi kehidupan manusia. Bagian terpenting dari kelapa adalah buahnya karena bagian tersebut dapat diolah. Salah satu bentuk olahan kelapa yaitu menjadi minyak kelapa.

Minyak adalah trigliserida (TG) yaitu hasil kondensasi satu molekul gliserol dengan tiga molekul asam lemak yang membentuk satu molekul TG dan tiga molekul air. Pada umumnya TG alam 
mengandung lebih dari satu jenis asam lemak. Minyak dapat digunakan sebagai medium penggoreng bahan pangan karena dapat berfungsi sebagai medium penghantar panas, menambah rasa gurih, menambah nilai gizi dan kalori dalam bahan pangan. Tetapi pemanasan minyak secara berulangulang pada suhu tinggi dan waktu yang cukup lama akan membuat minyak teroksidasi menghasilkan senyawa-senyawa radikal bebas yang merugikan kesehatan seperti kerusakan pada sel hepar (liver), jantung, pembuluh darah maupun ginjal (Halliwell et al,1989; Rukmini, 2007).

Berbagai macam persenyawaan organik dapat menghambat proses oksidasi disebut antioksidan. Antioksidan didefinisikan sebagai senyawa yang dapat menunda, memperlambat, dan mencegah proses oksidasi lipid. Antioksidan mampu menginaktivasi berkembangnya reaksi oksidasi, dengan cara mencegah terbentuknya radikal. Salah satu tanaman yang berpotensi sebagai antioksidan alami adalah kelor (Moringa oleifera, Lam). Pada tumbuhan kelor, daun kelor sendiri mengandung senyawa antioksidan yang dapat digunakan sebagai antioksidan pada minyak kelapa sehingga perlu dilakukan penelitian untuk mengetahui aktivitas antioksidan dalam daun kelor pada minyak kelapa.

\section{METODE PENELITIAN}

\section{Alat}

Alat yang digunakan yaitu spektrofotometer UV-Vis (PD 303S), rotary evaporator (Rotavapor R$215 \mathrm{BUCH}$ ), blender (Philips), ayakan 50 Mesh, neraca analitik (Ohauss), magnetic stirrer, hot plate, peralatan gelas (Pyrex), oven (Memert) dan shaker.

\section{Bahan}

Bahan yang digunakan yaitu daun kelor, minyak kelapa masak, methanol (merck), etanol 95\% (merck), amonia Pekat (merck), asam Sulfat $2 \mathrm{~N}$, asam asetat anhidrat, besi (III) klorida 1\%, pita magnesium, asam klorida pekat, DPPH 5 ppm (merck), asam asetat glasial (merck), kloroform (merck), kalium oodida (merck), natrium tiosulfat $0,01 \mathrm{~N}$ (merck), amilum pekat, indicator fenoftalein, $\mathrm{KOH} 0,1 \mathrm{~N}$, aquades, dan kertas saring.

\section{Prosedur Kerja}

\section{Pembuatan Serbuk Kelor}

Sampel (daun kelor segar) ditimbang sebanyak $1.395 \mathrm{~g}$ kemudian dikeringkan dengan mengunakan oven pada suhu $40^{\circ} \mathrm{C}$. Setelah benar-benar kering (berat konstan), sampel dihaluskan menggunakan blender kemudian diayak dengan menggunakan ayakan 50 Mesh, hingga diperoleh serbuk kelor.

\section{Ekstraksi (Maserasi) Daun kelor}

Ditimbang serbuk kelor kering sebanyak $500 \mathrm{~g}$ dimasukkan ke dalam botol reagen dan ditambahkan pelarut metanol p.a sebanyak $1000 \mathrm{~mL}$ kemudian diaduk menggunakan shaker selama $3 \times 24$ jam. Setelah itu, disaring menggunakan corong Buchner. Filtrat dari hasil disaring dimasukkan ke dalam botol reagen bersih. Kemudian dievaporasi untuk mendapatkan ekstrak dan ditimbang ekstrak metanol daun kelornya.

\section{Uji Fitokimia secara Kualitatif (Harborne, 1987)}

\section{Identifikasi kandungan alkaloid}


Sebanyak $1 \mathrm{~mL}$ ekstrak methanol daun kelor dimasukkan ke dalam tabung reaksi dan ditambahkan 5 tetes amonia pekat. Setelah itu, disaring kemudian ditambah $2 \mathrm{~mL}$ asam sulfat $2 \mathrm{~N}$ dan dikocok hingga memberi lapisan atas dan bawah. Larutan dibagi menjadi 2 bagian, pada tabung pertama ditambahkan 1 tetes larutan mayer dan tabung kedua ditambahkan 1 tetes pereaksi Dragendorf.

Identifikasi kandungan terpenoid

Sebanyak $1 \mathrm{ml}$ ekstrak metanol daun kelor dimasukkan ke dalam tabung reaksi. Kemudian ditambahkan asam asetat anhidrat dan asam sulfat pekat.

Identifikasi kandungan fenolik

Sebanyak 3 tetes ekstrak methanol daun kelor diteteskan pada pellet porselen. Kemudian ditambahkan metanol, lalu diaduk sampai homogen. Setelah itu ditambah $\mathrm{FeCl} 3$.

Identifikasi kandungan flavanoid

Sebanyak $1 \mathrm{~mL}$ ekstrak metanol daun kelor dimasukkan ke dalam tabung reaksi. Kemudian ditambahkan 5 tetes etanol, lalu dikocok sampai homogen. Kemudian, ditambahkan pita Mg dan 5 tetes $\mathrm{HCl}$ pekat.

Identifikasi kandungan saponin

Sebanyak $1 \mathrm{~mL}$ ekstrak metanol daun kelor dimasukkan ke dalam tabung reaksi. Kemudian ditambahkan $2 \mathrm{~mL}$ aquades, lalu dikocok sampai homogen. Setelah itu, dipanaskan selama 2-3 menit. Kemudian didinginkan dan dikocok dengan kuat.

Identifikasi kandungan tannin

Uji tannin dilakukan menurut Miranda (Sangi et al., 2008). Ekstrak metanol daun kelor sebanyak 20 mg ditambahkan 2-3 tetes larutan $\mathrm{FeCl} 3$ 1\%.

\section{Penentuan Panjang Gelombang Maksimum ( $\lambda$ maks)}

$1 \mathrm{~mL}$ larutan DPPH $5 \mathrm{ppm}$ ditambahkan $4 \mathrm{~mL}$ metanol di kocok homogeny dan diukur serapannya yang diperoleh pada rentang panjang gelombang 510-520 nm dengan blanko metanol.

\section{Uji aktivitas antioksidan menggunakan metode DPPH}

Uji aktivitas antioksidan penangkap radikal ekstrak metanol dilakukan dengan metode DPPH sesuai yang digunakan Molyneux (2004). Sebanyak $1 \mathrm{~mL}$ ekstrak metanol daun kelor dengan konsentrasi 5 ppm, 10 ppm, 15 ppm, 20 ppm dan 25 ppm ditambahkan ke dalam 2 mL DPPH 5 ppm. Campuran selanjutnya dikocok dan diinkubasi pada suhu kamar selama 30menit di tempat gelap. Larutan ini selanjutnya diukur absorbansinya pada $\lambda$ maks. Perlakuan yang sama juga diulangi dan dilakukan untuk larutan blanko terdiri dari $2 \mathrm{~mL}$ DPPH 5 ppm dan $1 \mathrm{~mL}$ metanol.

\section{Uji Kualitas Minyak Kelapa}

\section{Uji Kualitas minyak sebelum pemanasan Bilangan Peroksida}

Sebanyak 2 g minyak dimasukkan ke dalam erlenmeyer $250 \mathrm{~mL}$, kemudian ditambahkan $30 \mathrm{~mL}$ campuran larutan dari $20 \mathrm{~mL}$ asam asetat glacial, $25 \mathrm{~mL}$ etanol $95 \%$ dan $55 \mathrm{~mL}$ kloroform, ditambahkan $1 \mathrm{~mL}$ larutan $\mathrm{KI}$ jenuh, $30 \mathrm{~mL}$ aquades dan $0,5 \mathrm{~mL}$ larutan amilum pekat sehingga berwarna ungu kemudian dititrasi dengan larutan $\mathrm{Na2S} 2 \mathrm{O} 30,01 \mathrm{~N}$ sampai larutan berwarna kuning encer. Kemudian dicatat volume $\mathrm{Na} 2 \mathrm{~S} 2 \mathrm{O} 30,01 \mathrm{~N}$ yang terpakai.

\section{Bilangan Asam}

Sebanyak $2 \mathrm{~g}$ minyak dimasukkan ke dalam erlenmeyer $250 \mathrm{~mL}$, kemudian ditambahkan $50 \mathrm{~mL}$ etanol 95\% dan ditambahkan 3-5 tetes indikator fenolftalein dan dilakukan titrasi dengan larutan 
standar $\mathrm{KOH} 0,1 \mathrm{~N}$ hingga warna merah muda tetap (tidak berubah selama 15 detik). Kemudian dicatat volume $\mathrm{KOH} 0,1 \mathrm{~N}$ yang terpakai.

\section{Kadar air}

Sebanyak $2 \mathrm{~g}$ minyak dimasukkan ke dalam sebuah botol tertutup yang sudah diketahui beratnya. Botol ditimbang kemudian dikeringkan dalam oven pada suhu $105^{\circ} \mathrm{C}$ selama 3 jam. Minyak didinginkan dalam desikator, setelah dingin ditimbang dan dicatat berat minyak. Perlakuan diulangi hingga memperoleh berat konstan.

\section{Uji kualitas minyak setelah pemanasan pada suhu $200^{\circ} \mathrm{C}$ selama 15 menit}

Minyak kelapa dipanaskan pada suhu $180-200{ }^{\circ} \mathrm{C}$ selama 15 menit, setelah suhu $200{ }^{\circ} \mathrm{C}$ tercapai, selama itu lama pemanasan mulai dihitung. Selanjutnya minyak dibiarkan berkontak dengan udara bebas pada suhu kamar, namun terhindar dari terkena sinar matahari secara langsung serta pengotor lainnya. Setelah dingin proses pemanasan diulangi lagi sebanyak 2 kali. Minyak kelapa yang telah dipanaskan kemudian diuji kualitasnya (bilangan peroksida, bilangan asam dan kadar air) untuk melihat perubahan yang terjadi dalam minyak kelapa.

Uji kualitas minyak setelah penambahan ekstrak metanol daun kelor dengan konsentrasi masing-masing 1,3 , dan $5 \%(\mathrm{~b} / \mathrm{v})$

Ekstrak metanol daun kelor dengan konsentrasi masing-masing 1, 3, 5\% b/v dimasukkan ke dalam minyak, kemudian dipanaskan pada suhu $180-200{ }^{\circ} \mathrm{C}$ selama 15 menit, setelah suhu $200^{\circ} \mathrm{C}$ tercapai, selama itu lama pemanasan mulai dihitung. Selanjutnya minyak dibiarkan berkontak dengan udara bebas pada suhu kamar, namun terhindar dari terkena sinar matahari secara langsung serta pengotor lainnya. Setelah dingin proses pemanasan diulangi lagi sebanyak 2 kali. Minyak kelapa yang telah dipanaskan kemudian diuji kualitasnya (bilangan peroksida, bilangan asam, dan kadar air).

\section{HASIL PENELITIAN}

\section{Ekstraksi Daun Kelor}

Ekstraksi adalah proses pemisahan secara kimia dan fisika kandungan zat simplisia menggunakan pelarut yang sesuai. Proses ekstraksi dilakukan dengan cara maserasi menggunakan pelarut metanol. Pelarut metanol merupakan pelarut polar sehingga dapat melarutkan analit yang bersifat polar. Metanol dapat mengikat senyawa alkaloid, steroid, saponin, dan flavonoid dari tanaman (Thompson, 1985). Selanjutnya disaring dan dilakukan penguapan menggunakan evaporator untuk menghasilkan ekstrak metanol daun kelor dan diperolah ekstrak sebanyak 49,21 gram.

\section{Uji Fitokimia}

Uji fitokimia dilakukan untuk membuktikan adanya senyawa antioksidan yang terkandung dalam ekstrak metanol daun kelor. Hasil uji fitokimia ekstrak metanol daun kelor ditunjukkan pada Tabel 1. 
Tabel 1. Hasil Uji Fitokimia Ekstrak Metanol Daun Kelor

\begin{tabular}{cllc}
\hline No & $\begin{array}{l}\text { Golongan Senyawa } \\
\text { Metabolit Sekunder }\end{array}$ & \multicolumn{1}{c}{ Hasil Pengamatan } & Hasil \\
\hline 1. & Alkaloid & $\begin{array}{l}\text { Mayer : endapan putih } \\
\text { Dragendorf : endapan ungu }\end{array}$ & + \\
& & Hijau kekuningan & + \\
2. & Flavonoid & Terdapat Busa & + \\
3. & Saponin & Hijau kecokelatan & + \\
4. & Tanin & Ungu pekat & + \\
5. & Terpenoid & Orange & + \\
6. & Fenolik & & \\
\hline
\end{tabular}

\section{Alkaloid}

Pada pengujian alkaloid dilakukan penambahan $\mathrm{H} 2 \mathrm{SO} 4$ sebelum ditambahkan pereaksi (Mayer dan Dragendorf) karena alkaloid bersifat basa sehingga harus diekstrak dengan pelarut yang mengandung asam (Harbone, 1996). Untuk senyawa alkaloid pada pereaksi Meyer, hasilnya positif menunjukkan ekstrak metanol daun kelor mengandung alkaloid. Nitrogen pada alkaloid akan bereaksi dengan ion logam $\mathrm{K}^{+}$dari kalium tetraiodomerkurat (II) membentuk kompleks kaliumalkaloid yang ditunjukkan pada Gambar 1 (Marliana dkk, 2005).

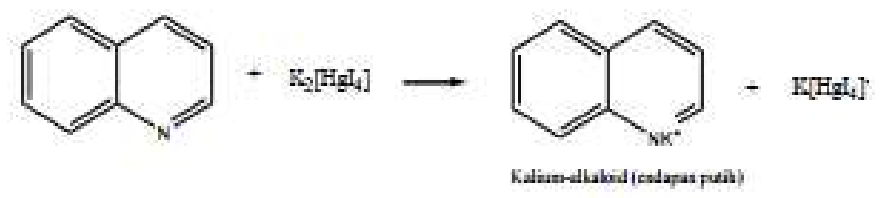

Gambar 1. Reaksi uji alkaloid dengan pereaksi Mayer

Pada uji alkaloid dengan pereaksi Dragendorf, nitrogen digunakan untuk membentuk ikatan kovalen koordinat dengan $\mathrm{K}^{+}$yang merupakan ion logam.

Reaksi alkaloid dengan perekasi Dragendorf ditunjukkan pada Gambar 2 (Marliana dkk, 2005).

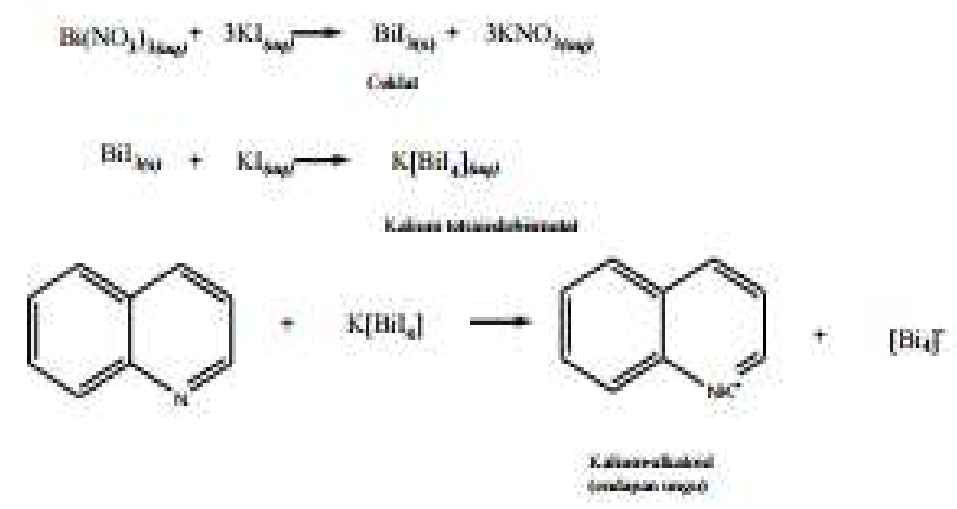

Gambar 2. Reaksi uji alkaloid dengan pereaksi Dragendrof 


\section{Flavonoid}

Pada identifikasi flavonoid dilakukan dengan mereaksikan sampel dengan serbuk $\mathrm{Mg}$ dan $\mathrm{HCl}$ pekat yang menunjukkan hasil yang positif karena larutan berubah menjadi kekuningan. Penambahan logam $\mathrm{Mg}$ dan $\mathrm{HCl}$ adalah Flavonol untuk mereduksi benzopiron yang terdapat dalam struktur flavonoid sehingga terbentuk garam falvilium berwarna merah atau jingga. Adapun reaksi yang terjadi antara senyawa flavonoid dengan $\mathrm{HCl}$ dan logam $\mathrm{Mg}$ terlihat pada Gambar 3 (Septyangsih, 2010).

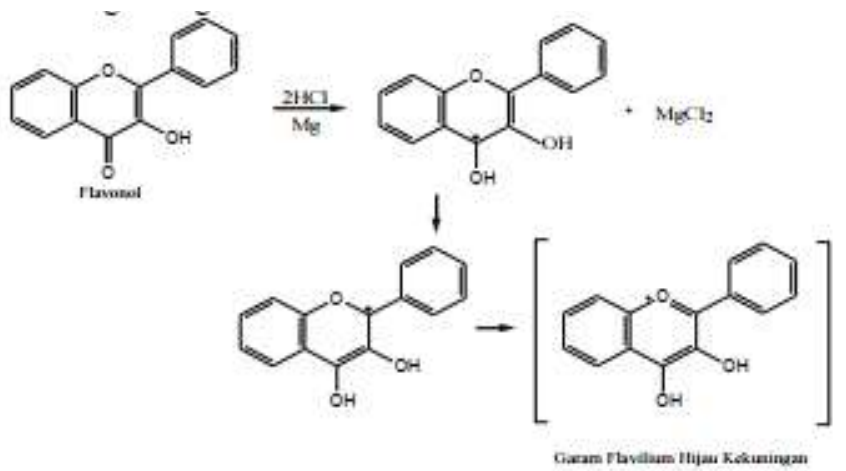

Gambar 3. Reaksi Falvonoid dengan logam $\mathrm{Mg}$ dan $\mathrm{HCl}$

\section{Saponin}

Pada identifikasi saponin sampel di uji dengan tambahkan air lalu di kocok kuat. Hasil menunjukkan positif karena larutan sampel terbentuk busa. Timbulnya busa menunjukkan adanya senyawa glikosida yang mempunyai kemampuan menghasilkan buih dalam air yang terhidrolisis menjadi glukosa dan senyawa lain. Reaksi yang terjadi dapat dilihat pada Gambar 4 (Marliana dkk, 2005).

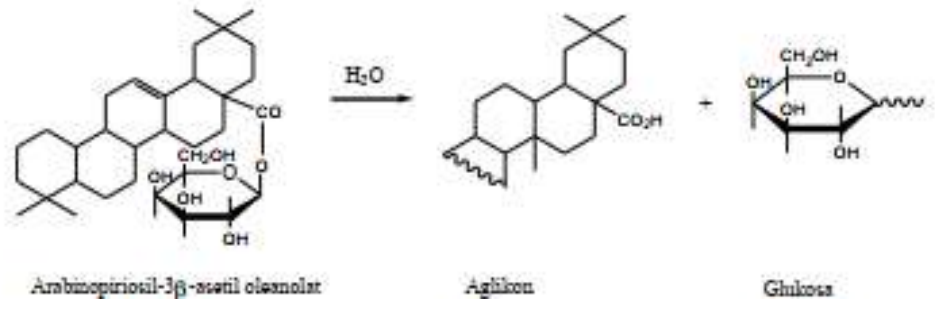

Gambar 4. Reaksi Hidrolisis saponim dalam air

\section{Terpenoid}

Pada identifikasi terpenoid pengujian golongan senyawa ini dilakukan dengan pereaksi Liebermann-Burchard (anhidrat asetat-H2SO4). Terpenoid yang dihidrolisis dengan asam sulfat pekat akan menghasilkan gugus hidroksil dan bereaksi dengan anhidrida asetat. Hasil positif pada uji ini ditandai dengan terbentuknya warna hijau pada larutan yang berasal dari reaksi antara terpenoid dengan $\mathrm{CH} 3 \mathrm{COOH}$ glacial dengan $\mathrm{H} 2 \mathrm{SO} 4$ pekat dan terbentuk warna ungu menandakan adanya terpenoid. Reaksi yang terjadi ditunjukkan pada Gambar 5 (Setiabudi dan Tukiran, 2017). 
<smiles>CC(C)CCC(C)C1CCC2C3C=CC4CC(C)CCC4(C)C3CCC2(C)C1CC(C)C</smiles><smiles>CC(C)CCC(C)C1CCC2C3C=CC4C([18OH])C(C)CCC4(C)C3CCC2(C)C1C(C)C</smiles>

Gambar 5. Reaksi Terpenoid dengan Pereaksi Liebermann-Burchard

\section{Fenolik}

Pada identifikasi fenolik dilakukan dengan mereaksikan larutan $\mathrm{FeCl} 31 \%$ dengan sampel menunjukkan hasil yang positif karena larutan berubah warna menjadi orange. Reaksi yang terjadi ditunjukkan pada Gambar 6 (Simaremare, 2014).

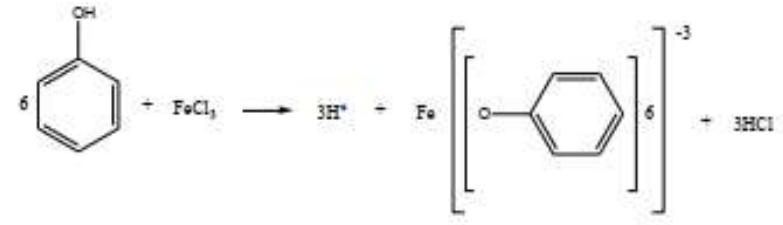

Gambar 6. Reaksi Uji Fenolik

\section{Tanin}

Pengujian tannin dilakukan dengan penambahan $\mathrm{FeCl} 31 \%$ pada ekstrak dan dan hasilnya positif ditunjukkan dari terbentuknya larutan berwarna hijau kehitaman karena reaski antara tannin dan $\mathrm{FeCl} 3$ membentuk senyawa kompleks. Terbentuknya senyawa kompleks antara tannin dan $\mathrm{FeCl} 3$ karena adanya ion $\mathrm{Fe}^{3+}$ sebagai atom pusat dan tannin memiliki atom $\mathrm{O}$ yang mempunyai pasangan electron bebas yang bisa mengkoordinasikan ke atom pusat sebagai ligannya. Reaksi Tanin dan FeCl3 ditunjukkan pada Gambar 7 (Marliana dkk, 2005).

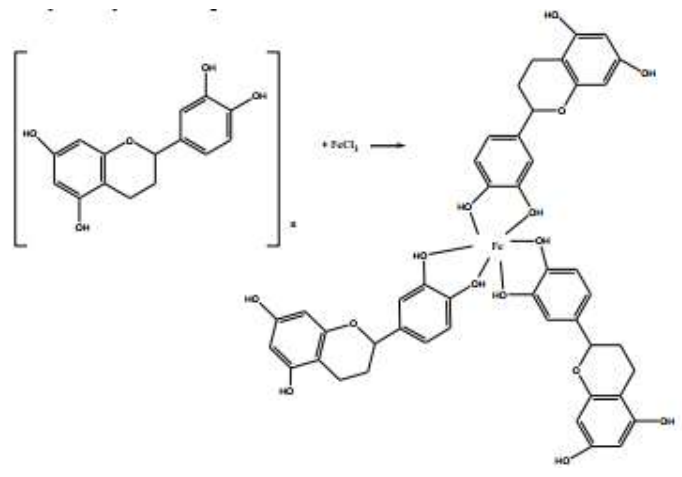

Gambar 7. Reaksi Tanin dengan $\mathrm{FeCl}_{3}$ 


\section{Uji Aktivitas Antioksidan Pada Ekstrak Metanol Daun Kelor}

Prinsip pengukuran aktivitas antioksidan secara kuantitatif menggunakan metode DPPH ini adalah adanya perubahan intensitas warna ungu DPPH yang sebanding dengan konsentrasi larutan DPPH tersebut. Radikal bebas DPPH yang memiliki elektron tidak berpasangan akan memberikan warna ungu. Warna akan berubah menjadi kuning ketika elektron berpasangan. Perubahan intensis warna ungu ini terjadi karena adanya peredaman radikal bebas yang dihasilkan oleh bereaksinya molekul DPPH dengan atom $\mathrm{H}$ yang dilepaskan oleh senyawa sampel sehingga terbentuk senyawa difenil pikril hidrazin dari warna ungu ke warna kuning. Reaksi antara antioksidan dengan DPPH dapat dilihat pada Gambar 8 (Prakash, 2011).

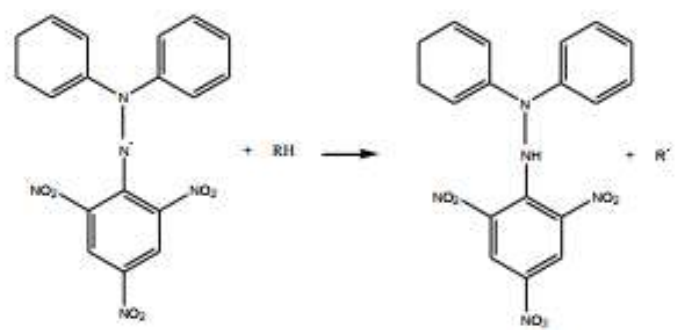

Gambar 8. Reaksi antara senyawa antioksidan dengan DPPH

Pengujian dilakukan menggunakan spektofotometer UV-Vis dan hasilnya berupa absorbansi. Hasil tersebut digunakan untuk penentuan nilai persen inhibisi kemudian menentukan nilai IC50. Nilai IC50 merupakan besarnya konsentrasi senyawa uji yang dapat meredam radikal sebanyak $50 \%$ (Molyneux, 2004). Hasil pengujian aktivitas antioksidan dari daun kelor ditunjukkan pada Gambar 9 .
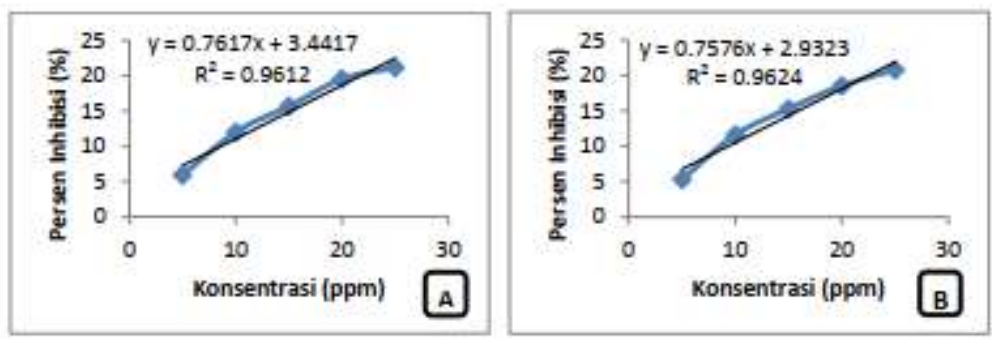

Gambar 9. Grafik Pengujian aktivitas antioksidan ekstrak metanol daun kelor (a) Larutan Pengulangan 1 dan (b) Larutan Pengulangan 2

Berdasarkan Gambar 9 menunjukkan hubungan antara konsentrasi dan persen inhibisi dari ekstrak metanol daun kelor sebagai antioksidan. Semakin besar konsentrasi ekstrak metanol daun kelor maka semakin besar nilai persen inhibisi pada kedua larutan uji tersebut. Adanya kenaikan persen inhibisi yang dipengaruhi oleh menurunnya nilai absorbansi. Penurunan nilai absorbansi ini juga dipengaruhi oleh tingginya konsentrasi sampel ekstrak metanol daun kelor. Data hasil Pengujian Aktivitas Antioksidan dapat ditunjukkan pada Tabel 2. 
Tabel 2. Data Hasil Pengujian Aktivitas Antioksidan Ekstrak Daun Kelor

\begin{tabular}{cccccc}
\hline $\mathbf{C}(\mathbf{p p m})$ & $\mathbf{A 1}$ & \% inhibisi 1 & A2 & \% inhibisi 2 & IC50 (ppm) \\
\hline 5 & 0,462 & 5,906 & 0,465 & 5,295 & \\
10 & 0,432 & 12,016 & 0,434 & 11,608 & \\
15 & 0,414 & 15,682 & 0,416 & 15,274 & \\
& & & & & \\
20 & 0,395 & 19,551 & 0,400 & 18,533 & \\
25 & 0,387 & 21,181 & 0,389 & 20,773 & \\
DPPH & 0,491 & & 0,495 & & \\
\hline
\end{tabular}

Berdasarkan Tabel 2 dapat disimpulkan bahwa semakin tinggi konsentrasi sampel maka semakin kecil nilai absorbansi sehingga mengakibatkan nilai persen inhibisi semakin besar. Dari hasil pengujian, ekstrak metanol daun kelor memiliki nilai IC50 sebesar 61,625 ppm dan termasuk antioksidan kuat (Molyneux, 2004).

\section{Uji Mutu kualitas Minyak Bilangan Peroksida}

Oksidasi pada minyak mengakibatkan peningkatan jumlah peroksida. Hal ini disebabkan oleh reaksi minyak dengan oksigen pada pemanasan. Asam lemak bebas tidak jenuh memiliki peluang beroksidasi pada ikatan rangkap menjadi senyawa hidroperoksida yang diukur dengan bilangan peroksida. Mekanisme reaksi asam lemak bebas tidak jenuh teroksidasi menjadi peroksida dapat ditunjukkan pada Gambar 10.

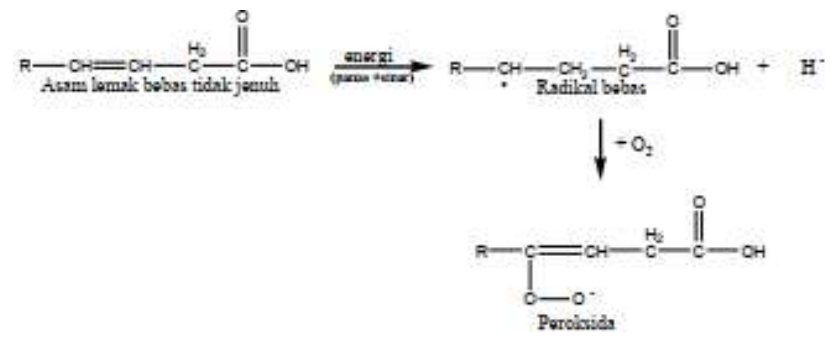

Gambar 10. Mekanisme reaksi oksidasi pada asam lemak tidak jenuh

Hasil bilangan peroksida minyak kelapa, tanpa dan penambahan ekstrak metanol daun kelor ditunjukkan pada Tabel 3.

Tabel 3. Hasil Uji Bilangan Peroksida pada minyak kelapa

\begin{tabular}{ccccccc}
\hline \multirow{2}{*}{ No. } & Sampel & \multicolumn{4}{c}{ Bilangan Peroksida Pada Waktu } & \multirow{2}{*}{ SNI } \\
\cline { 3 - 6 } & & \multicolumn{4}{c}{ Pemanasan } & \\
\cline { 3 - 6 } & & Menit & Menit & Menit & Menit & \\
\hline 1. & Tanpa ekstrak & 0,7074 & 4,2198 & 8,6569 & 10,3209 & \\
2. & Ekstrak 1\% & - & 2,5561 & 7,9483 & 8,7433 & $1,0-10,0$ \\
3. & Ekstrak 3\% & - & 2,7966 & 4,4563 & 6,7627 & mek/kg \\
4. & Ekstrak 5\% & - & 1,1716 & 3,8378 & 6,6043 & \\
\hline
\end{tabular}


Bilangan peroksida tanpa penambahan ekstrak daun metanol daun kelor pada suhu $200{ }^{\circ} \mathrm{C}$ serta waktu pemanasan 15, 30 dan 45 menit menunjukkan bahwa semakin lama minyak dipanaskan nilai peroksida yang diperoleh semakin besar. Kandungan peroksida yang terdapat dalam minyak menurun dengan penambahan ekstrak $1 \%$ dan semakin menurun pada penambahan $3 \%$ dan $5 \%$. Semakin banyak ekstrak yang ditambahkan pada minyak, semakin kecil nilai bilangan peroksida karena dalam ekstrak metanol daun kelor terdapat senyawa antioksidan. Hasil pengujian pada penambahan 5\% ekstrak metanol daun kelor pada pemanasan 15, 30 dan 45 menit bilangan peroksidanya $1,1716 \mathrm{mek} / \mathrm{kg}, 3,8378$ mek dan $6,6043 \mathrm{mek} / \mathrm{kg}$ jauh lebih rendah dari bilangan peroksida pada pemanasan tanpa ekstrak yaitu 4, $2198 \mathrm{mek} / \mathrm{kg}, 8,6569 \mathrm{mek} / \mathrm{kg}$ dan 10,3209 mek/kg. Mekanisme reaksi peroksida dengan senyawa kuersetin dapat ditunjukkan pada Gambar 11.

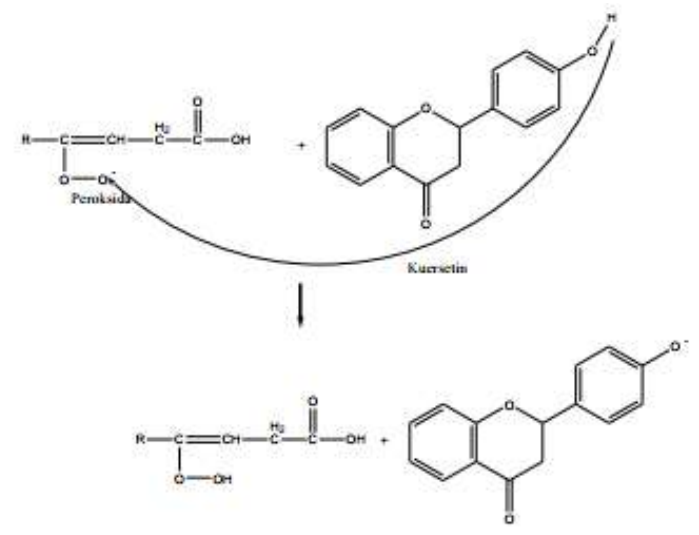

Gambar 11. Mekanisme reaksi peroksida dengan kuersetin

\section{Bilangan Asam}

Hasil pengujian bilangan asam minyak setelah pemanasan menunjukkan bilangan asam tersebut mengalami peningkatan, yang ditunjukkan pada Tabel 4.

Tabel 3. Hasil Uji Bilangan Peroksida pada minyak kelapa

\begin{tabular}{|c|c|c|c|c|c|c|}
\hline \multirow{2}{*}{ No. } & \multirow{2}{*}{ Sampel } & \multicolumn{4}{|c|}{ Bilangan Asam Pada Waktu } & \multirow{2}{*}{ SNI } \\
\hline & & $\begin{array}{c}0 \\
\text { Menit }\end{array}$ & $\begin{array}{c}15 \\
\text { Menit }\end{array}$ & $\begin{array}{l}30 \\
\text { Menit }\end{array}$ & $\begin{array}{c}45 \\
\text { Menit }\end{array}$ & \\
\hline 1. & Tanpa ekstrak & 0,5034 & 13,9533 & 25,9264 & 30,1511 & \multirow{4}{*}{$\begin{array}{l}0,6-2,0 \\
\mathrm{KOH} / \mathrm{g}\end{array}$} \\
\hline 2. & Ekstrak 1\% & - & 1,2522 & 1,6520 & 1,8931 & \\
\hline 3. & Ekstrak 3\% & - & 1,0065 & 1,2567 & 1,5040 & \\
\hline 4. & Ekstrak 5\% & - & 0,8871 & 0,8408 & 1,2676 & \\
\hline
\end{tabular}

Pada pemanasan 15 menit tanpa esktrak metanol daun kelor menunjukkan bilangan asam melebihi nilai standar yang dipersyaratkan $13,953 \mathrm{mgKOH} / \mathrm{g}$ sementara standar mutu 
yang ditetapkan oleh SNI yaitu nilai maksimal bilangan asam 2,0 $\mathrm{mgKOH} / \mathrm{g}$, berarti minyak kelapa telah mengalami reaksi oksidasi. Hal ini disebabkan karena senyawa peroksida dari asam lemak bebas tidak jenuh teroksidasi menghasilkan aldehid, selanjutnya teroksidasi lagi menghasilkan asam karboksilat yang menyebabkan terjadinya peningkatan nilai bilangan asam. Mekanisme reaksi oksidasi senyawa peroksida dapat ditunjukkan pada Gambar 12.

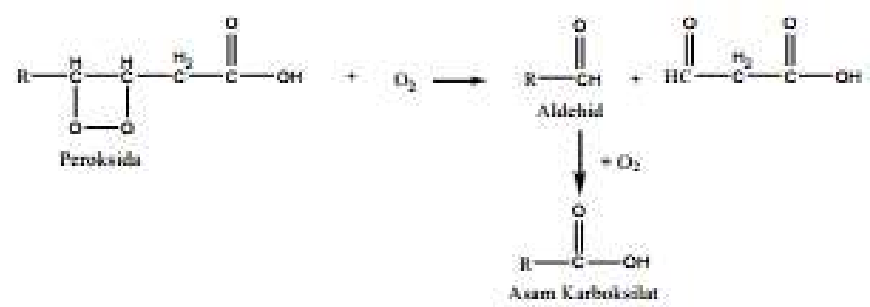

Gambar 12. Mekanisme reaksi oksidasi senyawa peroksida

Pada tabel 4 juga menunjukkan bahwa setelah penambahan ekstrak metanol daun kelor, bilangan asam pada minyak turun bahkan pada pemanasan 45 menit pun bilangan asamnya masih memenuhi syarat SNI dan layak dikonsumsi. Penurunan bilangan asam pada minyak yang telah dipanaskan kemungkinan disebabkan karena terjadi reaksi re-esterifikasi antara asam lemak dengan fraksi monogloserida atau digliserida pada minyak yang dipanaskan sehingga membentuk trigliserida (Ketaren, 1986).

\section{Kadar Air}

Kadar air adalah jumlah air yang terkandung dalam minyak yang menentukan kualitas minyak. Semakin kecil kadar air dalam minyak maka semakin baik kualitas minyak, karena adanya air dalam minyak memicu terjadi reaski hidrolisis yang akan mempengaruhi penurunan kualitas minyak. Pada suhu tinggi air akan menghidrolisis gliserida-gliserida menjadi gliserol dan asam-asam lemak bebas. Reaksi hidrolisis minyak dapat dilihat pada Gambar 13.

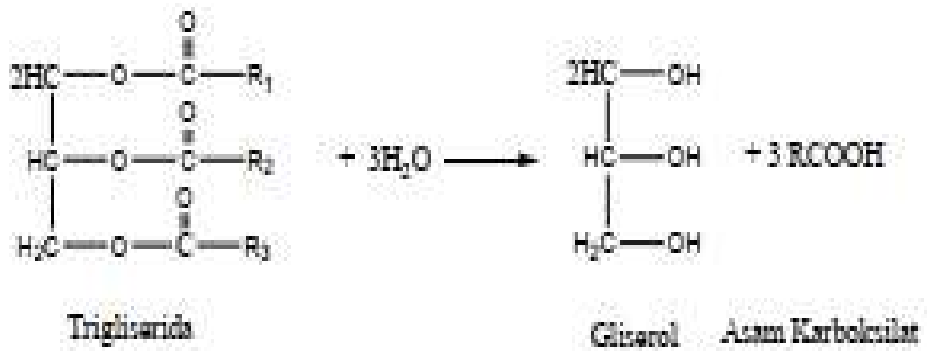

Gambar 13. Reaksi hidrolisi minyak

Dari Gambar 13 dapat dilihat bahwa minyak yang bereaksi dengan air akan menghasilkan asam karboksilat yang menyebabkan tingginya bilangan asam sehingga mempengaruhi kerusakan minyak. Hasil pengujian kadar air pada minyak ditunjukkan pada Tabel 5. 
Tabel 5. Hasil Uji Kadar Air Pada Suhu $200^{\circ} \mathrm{C}$

\begin{tabular}{ccccccc}
\hline No. & Sampel & \multicolumn{4}{c}{ Kadar air Pada Waktu } & \multirow{2}{*}{ SNI } \\
\cline { 3 - 6 } & & 0 & 15 & 30 & 45 & \\
& & Menit & Menit & Menit & Menit & \\
\hline 1. & Tanpa ekstrak & 0,0658 & 0,2168 & 0,1661 & 0,0980 & \\
2. & Ekstrak 1\% & - & 0,1978 & 0,1290 & 0,0896 & $0,01-0,30$ \\
3. & Ekstrak 3\% & - & 0,1999 & 0,1526 & 0,0987 & $\%$ \\
4. & Ekstrak 5\% & - & 0,2019 & 0,1334 & 0,0983 & \\
\hline
\end{tabular}

Tabel 5 menunjukkan kadar air tanpa penambahan ekstrak metanol daun kelor pada suhu 200 ${ }^{\circ} \mathrm{C}$ serta waktu pemanasan 15, 30 dan 45 menit masih memenuhi persyaratan mutu minyak kelapa yang ditetapkan oleh SNI 01-3742-2013 yaitu $\leq 3,0 \%$ (b/b). Penurunan kadar air pada minyak kelapa lebih besar ketika penambahan ekstrak metanol daun kelor $1 \%$ yaitu $0,1978,0,1290$ dan 0,0896 \% dibandingkan 3 dan $5 \%$. Hal ini disebabkan karena kemungkinan pada ekstrak terkandung air sehingga mempengaruhi adaanya kadar air dalam minyak.

\section{KESIMPULAN}

Berdasarkan hasil penelitian dapat disimpulkan bahwa:

1. Ekstrak metanol daun kelor mengandung senyawa alkaloid, steroid, flavanoid, tannin, terpenoid dan saponin.

2. Aktivitas antioksidan ekstrak metanol daun kelor menggunakan metode DPPH tergolong antioksidan kuat karena memiliki nilai IC50 61,625 ppm.

3. Kualitas minyak sebelum pemanasan tanpa penambahan ekstrak metanol daun kelor baik. Nilai bilangan peroksida $(0,7074 \mathrm{mek} / \mathrm{kg})$, bilangan asam $(0,5034 \mathrm{~g})$, dan kadar air $(0,0658 \%)$. Sedbilangann setelah pemanasan minyak tanpa penambahan ekstrak metanol daun kelor pada suhu $200{ }^{\circ} \mathrm{C}$ dengan waktu pemanasan 15,30 , dan 45 menit, kualitas minyak menurun. Nilai bilangan peroksida $(4,2198,8,6569$, dan 10,3209 mek/kg), bilangan asam $(13,9533,25,9264$, dan $30,1511 \mathrm{~g})$, dan kadar air $(0,2168,0,1661$, dan $0,0980 \%)$ yang menunjukkan minyak telah mengalami kerusakan.

4. Kualitas minyak semakin meningkat ketika penambahan ekstrak metanol daun kelor $5 \%$ pada pemanasan 15, 30 dan 45 menit. Nilai bilangan peroksida $(1,1716,3,8378$ dan 6,6043 mek/kg), bilangan asam $(0,8871,0,8408$ dan $1.2676 \mathrm{~g})$, dan kadar air dengan konsentrasi ektstrak $1 \%$ $(0,1978,0,1290$ dan $0,0896 \%)$.

\section{DAFTAR PUSTAKA}

Badan Standar Nasional. 2013. Standar Minyak Goreng. SNI 01-3741-2013. Jakarta.

Halliwell B., and Gutteridge JMC. 1989. Free Radical in Biology and Medicine. 3th edition. Oxford University Press.

Harbone, J. B. 1987. Metode Fitokimia. Penuntun Cara Modern Menganalisa Tumbuhan. Institut Teknologi Bandung. Bandung

Harbone, J. B. 1996. Metode Fitokimia: Penuntun Cara Modern Menganalisa Tumbuhan. Edisi Kedua. Institusi Teknologi Bandung. Bandung. 
Marliana, S.D., Suryanti, V., dan Suryono. 2005. Skrining Fitokimia dan Analisis kromatografi lapis tipis komponen kimia buah labu sia. (Sechium, edule Jacq, Swart) dalam ekstrak etanol Biofarmasi. 3(1).

Molyneux, P. 2004. The use of the stable free radikal diphenylpicrylhydrazyl (DPPH) for estimating antioxidant activity. Journal Science of Technology. 26(2)

Prakash, A. 2011. Antioxidant Activity. Medallion Laboratiries-Analytical Progress. 19(2): 1-4

Rukmini, A. 2007. Regenerasi Minyak Goreng Bekas Dengan Arang Sekam Menekan Kerusakan Organ Tubuh. Seminar Nasional Teknologi. 2007 (SNT 2007). ISSN: 1978-9777.

Sangi, M., MRJ. Runtuwene, HEI. Simbala dan VMA. Makang. 2008. Analisis Fitokimia Tumbuhan Obat di Kabupaten Minahasa Utara. Chem Prog. 1(1): 47-53

Septyaningsih, Dwi, et al. 2010. Analisis Sensori untuk Industri Pangan dan Agro. IPB Press. Bogor. Setiabudi dan Tukiran. 2017. Uji SKrining Fitokimia Ekstrak Metanol Kulit Batang Tumbuhan Klampok Watus (Syzygium litorale). UNESA Journal of Chemistry. 6(3): 155-160.

Thompson, E. B. 1985. Drug Bioscreening. America: Graceway Publishing Company, Inc. Pp. 40, 118. 